\title{
Eukaryote microbes potential for bioflocs in the swamp aquaculture
}

\section{Potensi mikrob eukariot untuk bioflok akuakultur lahan rawa payau}

\author{
Marini Wijayanti ${ }^{1 *}$, Tanbiyaskur'1, Dade Jubaedah'1 , Ade Bayu Saputra ${ }^{1}$, Karta Sari \\ Genti $^{1}$, Agustina ${ }^{1}$, Nabila Saraswati ${ }^{1}$, Siti Yuliani ${ }^{1}$, Hary Widjajanti ${ }^{2}$ \\ 'Program Study of Aquaculture, Faculty of Agriculture, University of Sriwijaya, South Sumatera, Indonesia \\ ${ }^{2}$ Department of Biology, Program Study of Biology, Faculty of Mathematics and Natural Sciences, \\ University of Sriwijaya, South Sumatera, Indonesia \\ *Corresponding author : mariniwijayanti@fp.unsri.ac.id
}

(Received May 30, 2017; Accepted July 30, 2019)

\begin{abstract}
Eucaryote microbes have an important role in forming bioflocs in the brackishwater aquaculture ponds. Bioflocs become potential live feed for milkfish or crustacea. This study aimed to identify the potential of eukaryotic microbes in the brackishwater aquaculture as the biofloc candidates potential development. This study was done through the water quality assessment and potential indigenous microbes isolation approach. Sampling was retrieved from the water subcomposite and sediment on each intertidal inlet and outlet. The water quality of brackishwater pond and intertidal swamp tended to lack of nutrient as containing inoptimal dissolved oxygen, salinity, $\mathrm{pH}$, and ammonia content for the milkfish culture. Therefore, liming and fertilizing should be done to enrich the indigenous microbes. Eucaryote microbe isolated from the enrichment media was the aquatic fungi (multicellular and unicellular fungi) and microalgae (bacillariophyta, chlorophyta, and cyanophyta). Fungi and yeast formed a floculation with microalgae. This form will become a biofloc candidate as a live feed and water quality controller for the development of brackishwater aquaculture in the swamp area.
\end{abstract}

Keywords: eucaryote microbes, biofloc, aquaculture, pond, brackish water swamp

\begin{abstract}
ABSTRAK
Mikrob eukariot berperan penting dalam pembentukan bioflok di tambak budidaya pada lahan rawa payau. Bioflok menjadi pakan alami untuk budidaya ikan bandeng atau udang. Tujuan riset ini adalah mengidentifikasi mikrob eukariot rawa payau potensial untuk pengembangan kandidat bioflok di akuakultur rawa payau. Riset ini dilakukan dengan pendekatan kualitas air serta isolasi mikrob indigenous tambak dan rawa pasang surut untuk mendapatkan isolat mikrob potensial sebagai kandidat pembentuk bioflok. Sampling dilakukan secara subkomposit pada air dan sedimen di setiap inlet dan outlet pasang surut. Kualitas air tambak dan rawa pasang surut menunjukkan kondisi oksigen terlarut, salinitas, $\mathrm{pH}$, dan amonia berada di luar batas optimum budidaya ikan bandeng, sehingga perlu dilakukan pengapuran dan pemupukan untuk memperbanyak mikrob indigenous-nya. Isolasi mikrob eukariot dari media pengayaan diperoleh jenis fungi akuatik yang multiseluler dan uniseluler, sedangkan mikroalga yang diperoleh yaitu dari golongan Bacillariophyta, Chlorophyta, dan Cyanophyta. Fungi yang dapat membentuk hifa dapat merangkai mikroalga dan khamir untuk membentuk flok. Susunan ini diharapkan dapat menjadi bahan bioflok yang berguna sebagai pengendali kualitas air sekaligus pakan alami bagi pengembangan budidaya di lahan rawa payau.
\end{abstract}

Kata kunci: mikrob eukariot, bioflok, budidaya, tambak, rawa payau 


\section{INTRODUCTION}

Brackishwater aquaculture is shrimp and fish culture in the pond using brackishwater applied at about 200,000 ha along with the coastal areas (Kumaran et al., 2018). The brackish wetland is usually a swamp that has a low fertility rate and $\mathrm{pH}$ level, making it less suitable for agricultural development. The development of aquaculture is expected to increase this land productivity and improve the local people welfare. The potential utilization of swamp water is still great for the brackishwater aquaculture industry. The development of aquaculture on the intertidal brackish land continues to be carried out mainly for the enhancement of marginal land productivity and achieving the fish culture production target.

The natural productivity of the swamp water becomes one of the important parts of the development of the swamp aquaculture. Determining the level of natural productivity usually depends on the water primary productivity, namely phytoplankton. Phytoplankton comes from in situ microalgae that will symbiotically relate to other aquatic microbes to form a basic food chain in the brackish wetland (Madigan et al., 2015). The microbial community is a key player in the nutrient cycle process and maintenance, as well as the fish health in the aquaculture system. The composition and function of eukaryote microbes in the aquaculture system is still much unknown (Boaventura et al., 2018). Therefore, microbial abundance can be used as an ecological approach in the sustainable development of sustainable swamp aquaculture. The swamp fish culture has much been done by the restation system without water exchange. One method for the fish and shrimp culture intensification without the water exchange can be done by the biofloc development (effective microbial groups). This makes the aquaculture activities more sustainable in terms of production as it maintains water quality, efficient feed, and culture biota health (Martinez-Porchas $\&$ Martinez-Cordova, 2012).

The aquatic microorganisms play an important role in the water ecosystem and biogeochemical cycles (De Melo et al., 2018). The eukaryote microbes, comprising microalgae, fungi, and microzooplankton, are important components of water productivity. These organisms combine themselves into the water mutualism symbiosis. The aquatic lichene has been found in the brackishwater as well as the terrestrial area. Lychene is a symbiosis between fungi and photosynthetic algae or cyanobacteria. This symbiosis is the biofloc starter applied to shrimp, milkfish, and fish ponds. The microbial plankton community forming flocs becomes is important in the pelagic food nets (Easson \& Lopez, 2019).

The brackishwater quality is beneficial for cultured fish growth and survival (Venkatachalam et al., 2018). The aquatic microbial flocculation can be a simple technology to control the water quality, feed, even disease prevention (Crab et al., 2012). The successful application of bioflocs for sustainable aquaculture development is determined by the nutrient availability, one of which is the $\mathrm{C}$ and $\mathrm{N}$ ratio in the culture medium (Pérez-Fuentes et al., 2016). These nutrients are utilized to proliferate microbial inoculants given in the culture media. The in situ microbes given nutrients will develop according to the ecosystem requirement or depending on the microbial composition in the ecosystem. This makes the microbial candidate isolation is necessary to be utilized as Bioflocs former based on the condition of land and water quality during the aquaculture activities. This study aimed to identify the potential of the eukaryotic microbes of swamp area for the biofloc candidate development in the swamp culture.

\section{MATERIALS AND METHODS}

This study comprised four steps, namely sampling, cultivation-enrichment, observation, and microscopic identification of the eukaryote microbes.

\section{Sampling}

Sampling was performed on NovemberDecember 2016 in the swamp area of Tanjung Lago Village, Banyuasin, South Sumatra. The water samples were obtained from four locations (two locations from the brackishwater culture ponds, and two other locations from swamp water areas). Two sampling points represented the intertidal inlet and outlet on each location subcompositely. The water samples were obtained for further water quality and microbial isolation. The in situ water samples were analyzed based on the quality through the temperature, brightness, $\mathrm{pH}$, salinity, dissolved oxygen, and total dissolved solid parameters. Meanwhile, water samples for the other water parameter analysis (BOD, COD, ammonia, nitrate, nitrite, phosphate, $\mathrm{Pb}, \mathrm{Hg}$, and $\mathrm{Cd}$ ) were kept on the refrigerator. The water sample for the microbial isolation was filtered 
using a plankton net and kept cool in the bottle at the refrigerator temperature (Addo et al., 2016; Madigan et al., 2020).

\section{Enrichment and cultivation}

Water samples of $200 \mathrm{~mL}$ (made with two replications) on each location were moved into the Erlenmeyer. These samples were enriched with the sterilized technical fertilizer $\left(\mathrm{TSP}\left(\mathrm{Ca}_{3}\left(\mathrm{PO}_{4}\right)_{2}\right)\right.$, urea $\left(\mathrm{CO}\left(\mathrm{NH}_{2}\right)_{2}\right)$, ZA $\left(\mathrm{NH}_{4}\right)_{2}\left(\mathrm{SO}_{4}\right)$, Gardasil B) at pH 6-7 under a tube lamp with 500 - 1000 lux. Agitation was performed through aeration for 24 hours, then shaken at 3 times a day for 1 minute every 08.00, 12.00, and 16.00 (GMT+7) until all samples were ready to be identified and isolated (7-14 days). The fungi cultivation was performed using potato dextrose agar (PDA) from the diluted $\left(10^{-4}\right)$ enriched isolate using physiological $\mathrm{NaCl}$ and grown for 5 days. and shook 3 times a day.

\section{Observation and identification}

The eukaryote microbial identification containing phytoplankton and zooplankton was performed using a microscope with 40 and 100 times magnification and assisted with the identification book of Davis (1955). The fungi identification was performed until the proposed groups from the multicellular and unicellular based on the morphological observation. The morphological difference was observed from the specific characteristics of hyphae cells (Madigan et al., 2020).

\section{Data analysis}

The observational data of eukaryote microbial types were analyzed descriptively along with the percentage of relative abundance on each plankton type and uniformity on each habitat (swamp or pond). The water quality measurement data result were also analyzed descriptively using the dendrogram analysis (Minitab 14 program) and grouped based on the uniformity level between the eukaryote microbial habitats.

\section{RESULTS AND DISCUSSION}

The swamp water and sediment sampling on the intertidal area was performed during the low-tide reaching the up-tide. Sampling was performed on two areas representing milkfish/ shrimp culture ponds (T.I and T.II) and intertidal swamp areas (R.I and R.II) (Figure 1a and 1b). Samples were taken from two points representing the intertidal inlet and outlet. The inlet point was closed to the water entrance from the river, while the outlet point was closed to the seawater way (based on the freshwater flow).

The data obtained from the first sampling (in situ) is shown in Table 1 . The water quality result indicates that the intertidal swamp areas have a higher $\mathrm{pH}$ tendency than the common water. This is because there was a liming condition during the culture preparation process. High $\mathrm{pH}$ level tendency from acid to neutral will be followed with the high microbial diversity in the water (Wijayanti et al., 2019), improving the opportunity to obtain the prospective microbial isolates to maintain the water quality, specifically when utilized as the fish swamp culture water source.

The water quality was still at the range of the national standard for brackish water aquaculture shrimp and milkfish), as the brightness was $30-40 \mathrm{~cm}$ and nitrite content was $<3 \mathrm{mg} / \mathrm{L}$ (SNI 6418.3, 2013; WWF, 2014). Some parameters were outside the optimum range of the national standard, as the dissolved oxygen should be 4-8 $\mathrm{mg} / \mathrm{L}$, ammonia should be $<0.01 \mathrm{mg} / \mathrm{L}$, total organic matter should be $20-25 \mathrm{mg} / \mathrm{L}, \mathrm{pH}$ should be 7.5-8.5, and salinity should be 5-25 g/L (SNI 6418.3, 2013; WWF, 2014). The salinity level in location 1 was less than the optimum salinity range
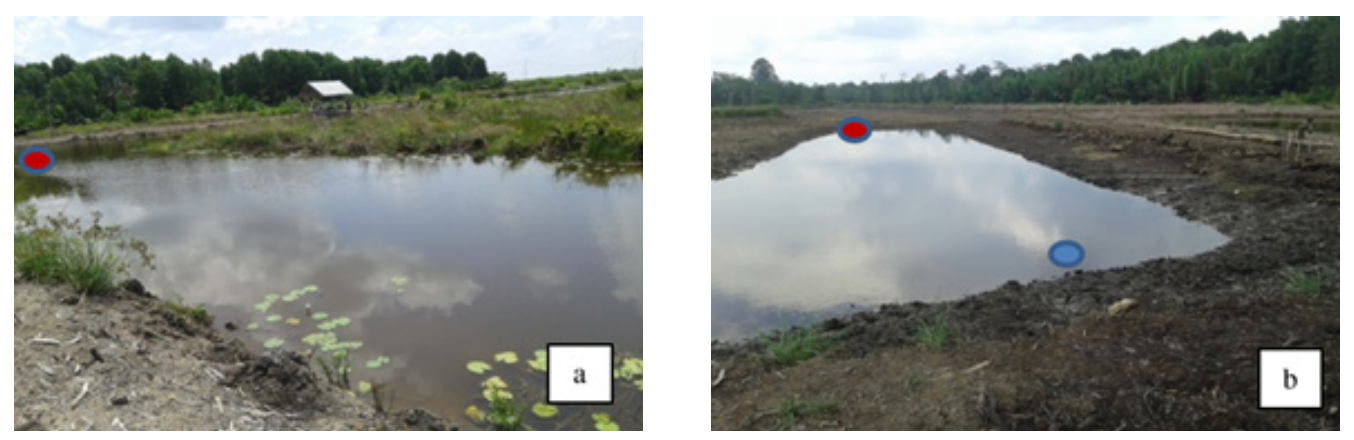

Figure 1. Area of swamp culture water of milkfish and shrimp pond (a), and intertidal swamp water area (b). Note: inlet $\bigcirc$, outlet flow 
Table 1 . The water quality of swamp pond (T) and intertidal swamp (R)

\begin{tabular}{ccccccccccc}
\hline \multirow{2}{*}{ No. } & \multirow{2}{*}{ Parameter } & \multirow{2}{*}{ Unit } & \multicolumn{7}{c}{ Location } \\
\cline { 5 - 10 } & & & T.I.1 & T.I.2 & T.II.1 & T.II.2 & R.I.1 & R.I.2 & R.II.1 & R.II.2 \\
\hline 1 & Depth & $\mathrm{cm}$ & 58.00 & 61.00 & 50.00 & 58.00 & 51.00 & 151.00 & 72.00 & 60.00 \\
2 & Salinity & $\mathrm{g} / \mathrm{L}$ & 2 & 1 & 12 & 18 & 20 & 9 & 11 & 19 \\
3 & Temperature & ${ }^{\circ} \mathrm{C}$ & 33.4 & 34.3 & 33.8 & 34.4 & 33.5 & 32.5 & 30.6 & 30.6 \\
4 & $\mathrm{pH}$ & $\mathrm{unit}$ & 7.33 & 7.17 & 7.39 & 7.56 & 6.68 & 7.06 & 6.82 & 6.85 \\
5 & Brightness & $\mathrm{cm}$ & 46.00 & 48.75 & 41.00 & 36.50 & 48.00 & 59.00 & 61.25 & 42.00 \\
6 & $\mathrm{TDS}$ & $\mathrm{g} / \mathrm{L}$ & 3.26 & 3.25 & $>10$ & $>10$ & $>10$ & 4.53 & $>10$ & $>10$ \\
7 & DHL & $\mathrm{ms}$ & 5.2 & 5.6 & 19.8 & 19.50 & $>20$ & 7.9 & 19.1 & $>20$ \\
8 & $\mathrm{DO}$ & $\mathrm{mg} / \mathrm{L}$ & 3 & 2.9 & 2.8 & 2.4 & 2.6 & 3 & 2.8 & 2.8 \\
9 & BOD 5 & $\mathrm{mg} / \mathrm{L}$ & 0.9 & 2.4 & 1.8 & 1.9 & 0.7 & 2.3 & 0.9 & 1.5 \\
10 & $\mathrm{COD}$ & $\mathrm{mg} / \mathrm{L}$ & 8 & 9 & 6 & 8 & 9 & 7 & 10 & 7 \\
11 & Ammonia & $\mathrm{mg} / \mathrm{L}$ & 0.09 & 0.12 & 0.14 & 0.19 & 0.33 & 0.26 & 0.24 & 0.19 \\
12 & Nitrate & $\mathrm{mg} / \mathrm{L}$ & 0.06 & 0.09 & 0.09 & 0.01 & 0.14 & 0.10 & 0.09 & 0.08 \\
13 & Nitrite & $\mathrm{mg} / \mathrm{L}$ & 0.019 & 0.021 & 0.018 & 0.019 & 0.024 & 0.027 & 0.021 & 0.018 \\
14 & Phosphate & $\mathrm{mg} / \mathrm{L}$ & 0.12 & 0.12 & 0.09 & 0.09 & 0.01 & 0.01 & 0.04 & 0.04 \\
15 & TOC & $\mathrm{mg} / \mathrm{L}$ & 26.3 & 26.3 & 27.8 & 27.8 & 26.6 & 26.6 & 19.3 & 19.3 \\
16 & Pb & $\mathrm{mg} / \mathrm{L}$ & $<0.003$ & $<0.003$ & $<0.003$ & $<0.003$ & 0.020 & 0.020 & 0.020 & 0.020 \\
17 & Hg & $\mathrm{mg} / \mathrm{L}$ & $<0.0001$ & $<0.0001$ & $<0.0001$ & $<0.0001$ & $<0.0001$ & $<0.0001$ & $<0.0001$ & $<0.0001$ \\
18 & $\mathrm{Cd}$ & $\mathrm{mg} / \mathrm{L}$ & $<0.0015$ & $<0.0015$ & $<0.0015$ & $<0.0015$ & $<0.0015$ & $<0.0015$ & $<0.0015$ & $<0.0015$ \\
\hline
\end{tabular}

Note : T.I.1 = Inlet pond 1, T.I. $2=$ Outlet pond 1, T.II.1 $=$ Inlet pond 2, T.II. $2=$ Outlet pond $2 ;$ R.I.1 = Inlet swamp 1, R.I.2 = Outlet Swamp 1, R.II.1 = Inlet swamp 2, R.II.2 = Outlet swamp 2; 1 and 2 are the replication codes representing the habitat

for milkfish culture. The dissolved oxygen in ponds and swamps were relatively low. The $\mathrm{pH}$ value was also averagely low from the optimum range. The ammonia value both in ponds and swamps brackish was still higher than the maximum limit for milkfish culture. Thereby, the water quality system needs to be improved to customize with the water quality standard for milkfish culture. The aeration system improvement, liming, and seawater flow addition can increase the dissolved oxygen, reduce unionized ammonia level, besides increasing the $\mathrm{pH}$ and salinity level based on the optimum condition of milkfish culture.

The water quality condition improvement can be done by liming combined with fertilization to increase the swamp microbes potential as probiotics that can improve and maintain the water quality and cultured biota. The swamp microbes containing bacteria, fungi, and phytoplankton are expected to be the microbial candidates as the live feed material for bioflocs. Swamp bacteria symbiotic with fungi can help maintain the water quality by reducing the sulfate, nitrite-ammonium (denitrifier and anammox), and dissolved carbon in the swamp water including the dark water area
(Holland et al., 2012). Phytoplankton that grows in the swamp bioflocs has a role to supply the dissolved oxygen through photosynthesis.

The group analysis result on the water quality data presented as a Dendrogram (Figure 2) indicates that among the four sampling locations (T I, T II, R I, and R II) have no water quality condition difference. This was shown from the water uniformity level among locations that were still above 95\%, which means that the swamp water has no different from the pond water. The water quality in pond 2 (TII) and swamp water (RII and RI) were separated from pond 1 (T1). This indicates that the water quality in pond 2 was still closely similar to the swamp water. This also means that pond 2 has not been given much intensive treatment for the cultured biota. In contrast, the water quality has been improved more in pond 1 , although there was no significant difference with pond 2 and swamp water. Similar water quality condition is suspectively due to the swamp water as the cultured ponds were still semi-intensive as swamp ponds are usually used for semi-intensive culture of milkfish and shrimp with unmeasured feeding and only relying on the live feed. 


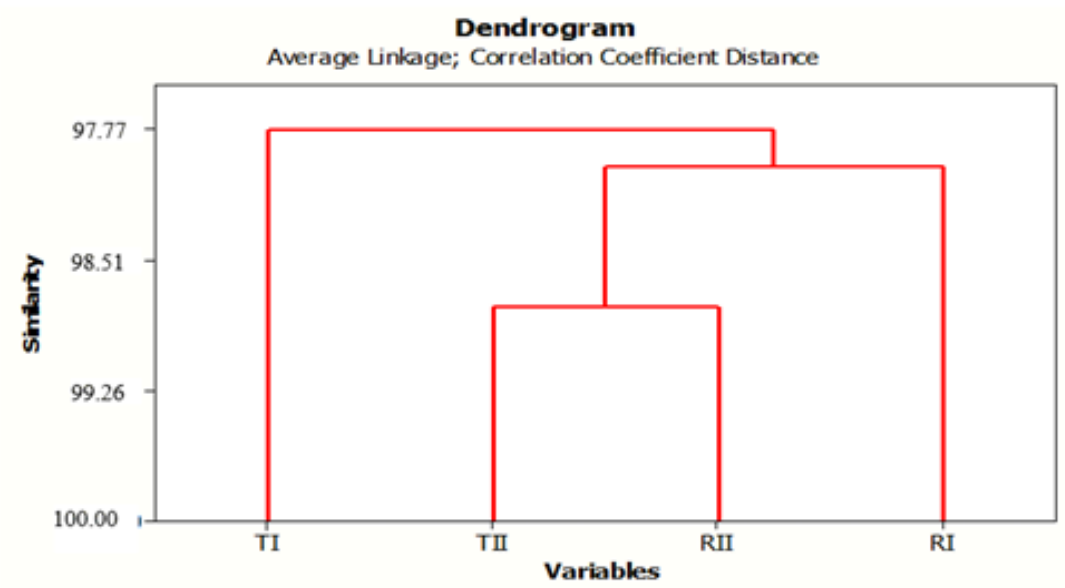

Figure 2. The pond water quality on ponds (T) and swamp areas (R) using Minitab 14. Note : T.I : Pond 1, T.II : Pond 2 ; R.I : swamp 1, R.II. : swamp 2; 1 and 2 are the replication codes representing the habitat.
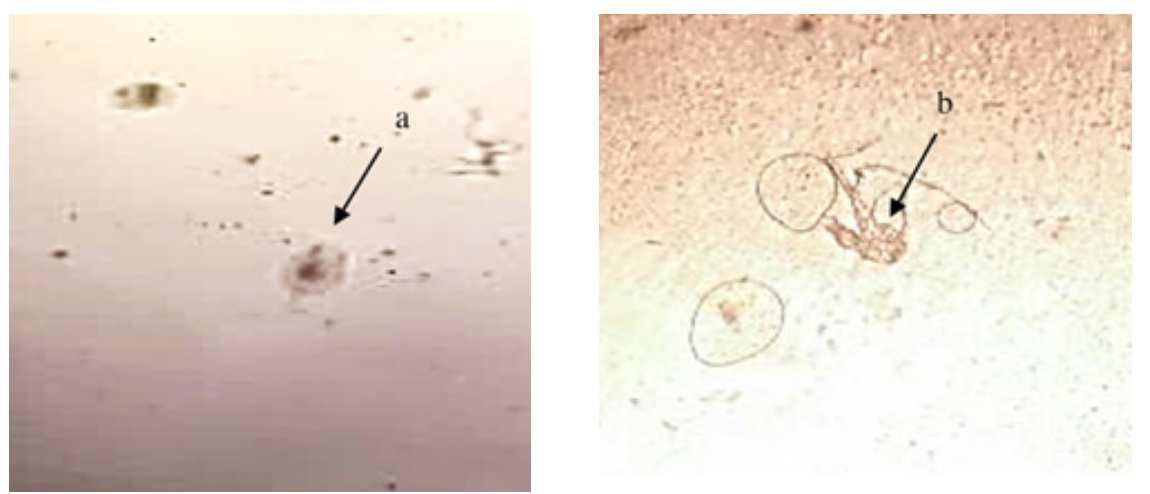

Figure 3. Microzooplankton observation and identification using a microscope with 40x magnification (a. Brachionus ; b. Crustacea).

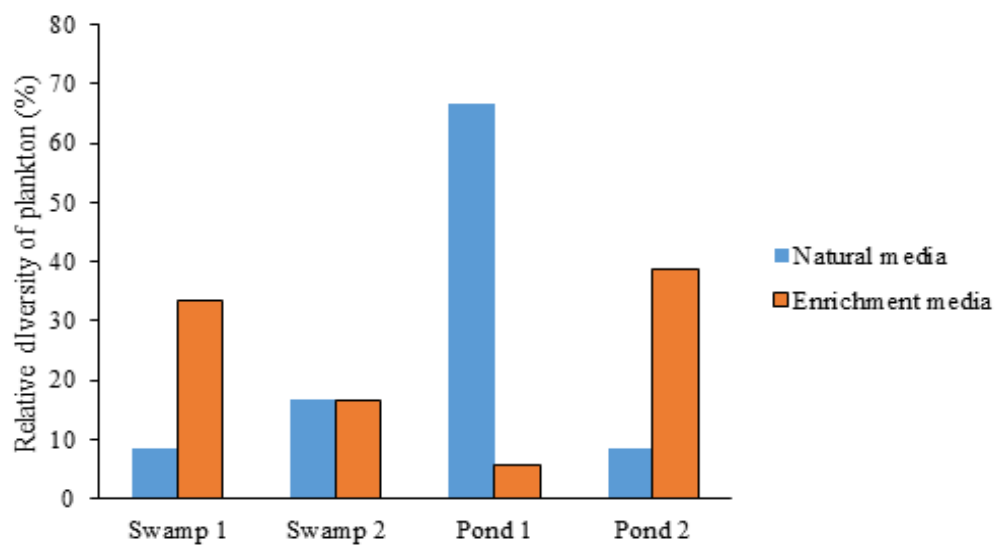

Figure 4. The relative percentage of plankton diversity on different locations

Microzooplankton, such as Brachionus and Crustacean type (Figure 3) contained on this swamp water can be utilized as the culture biota live feed, specifically during the larval phase.

The relative plankton diversity from the total identified plankton on each location was compared to the total identified plankton type. The relative plankton diversity was obtained from the ratio of plankton type found on the media and the total identified plankton type on all locations. The relative plankton diversity per location compared among the different media and enrichment can be seen in Figure 4.

The lack of plankton type found in the samples can be caused by a less fertilized swamp of and dissolved oxygen reduction due to the high organic matter decomposition. Pond and swamp conditions with little or without water exchange will reduce the phytoplankton nutrients and dissolved oxygen level. In addition, to become the natural aerator that enhances the DO in the pond, the water exchange will provide the nutrient 


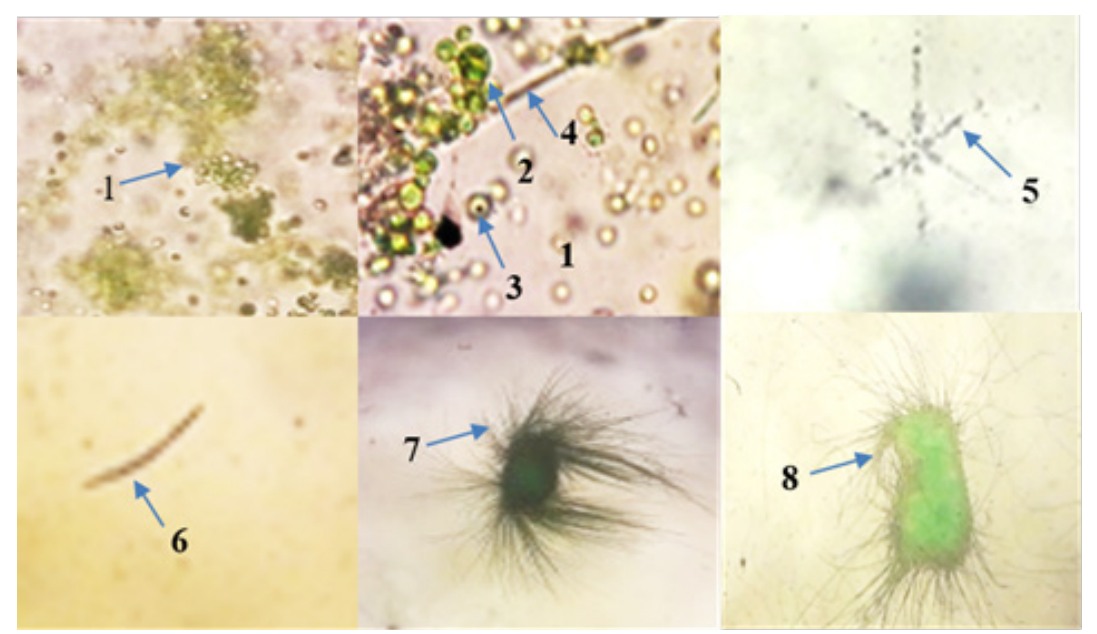

Figure 5. The microalgae identification from water pond sample after enrichment. Note: Phytoplankton types and the magnification: 1. Chlorella (40x), 2. Gleocapsa (100x), 3. Aphanotece (100x), 4. Oscilatoria (100x), 5. Asterionella (100x), 6. Thallasiothrix (100x), 7. Golenkinia (100x), 8. Franceia (100x).

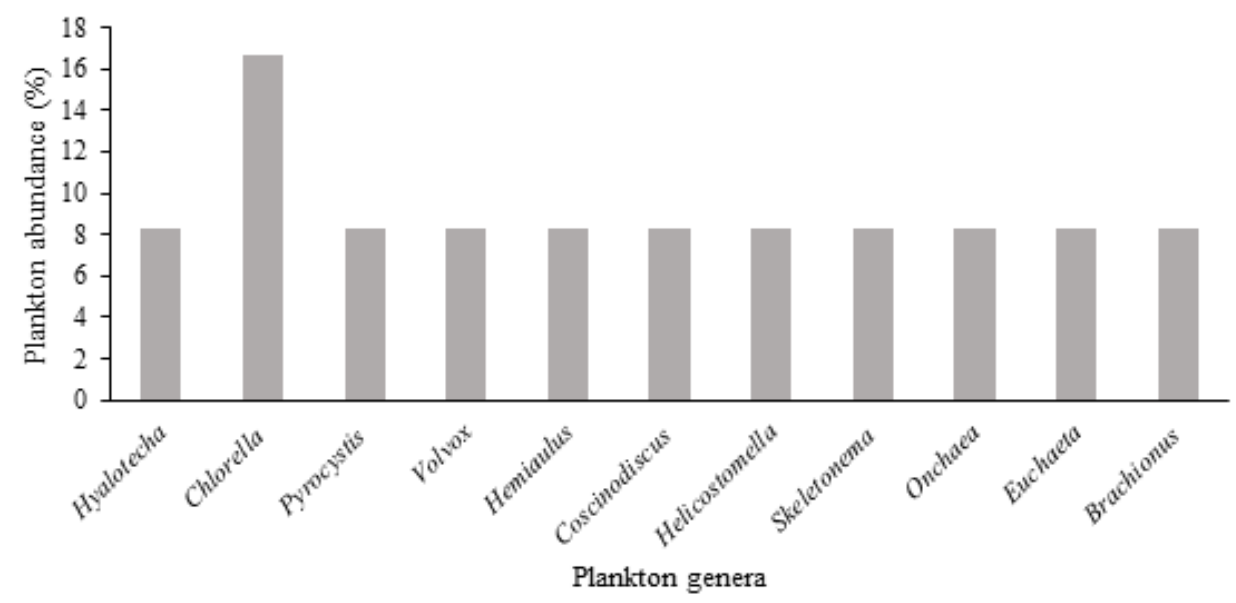

Figure 6. Ahundance of nlankton in natural hahitat medium

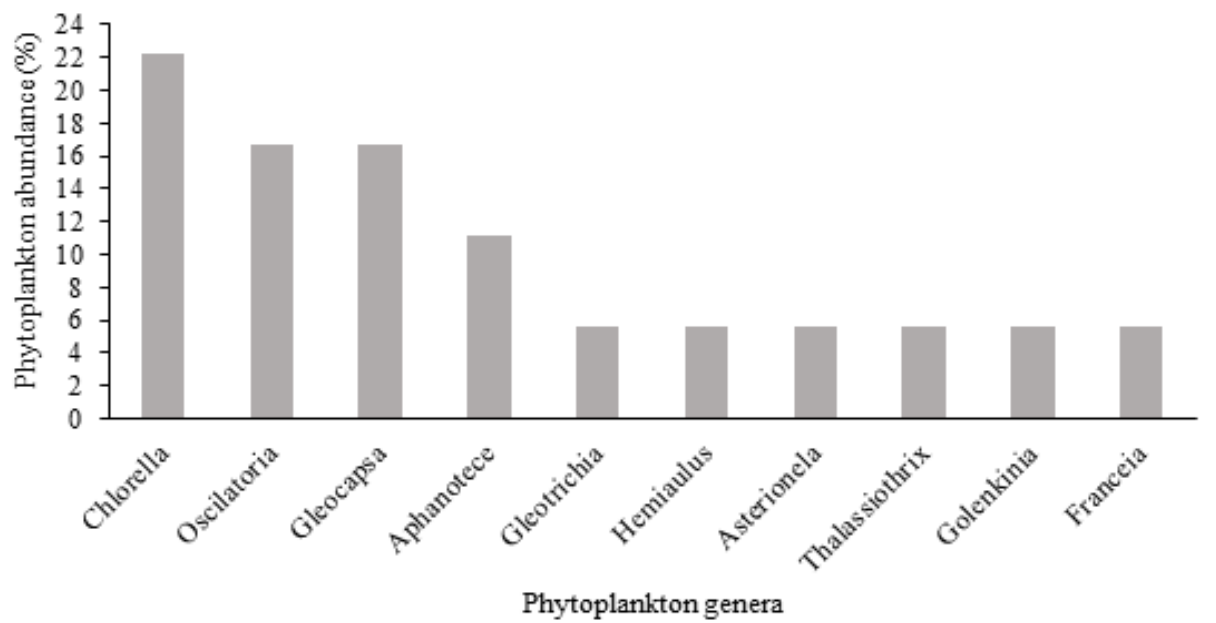

Figure 7. Abundance of phytoplankton in enrichment medium 


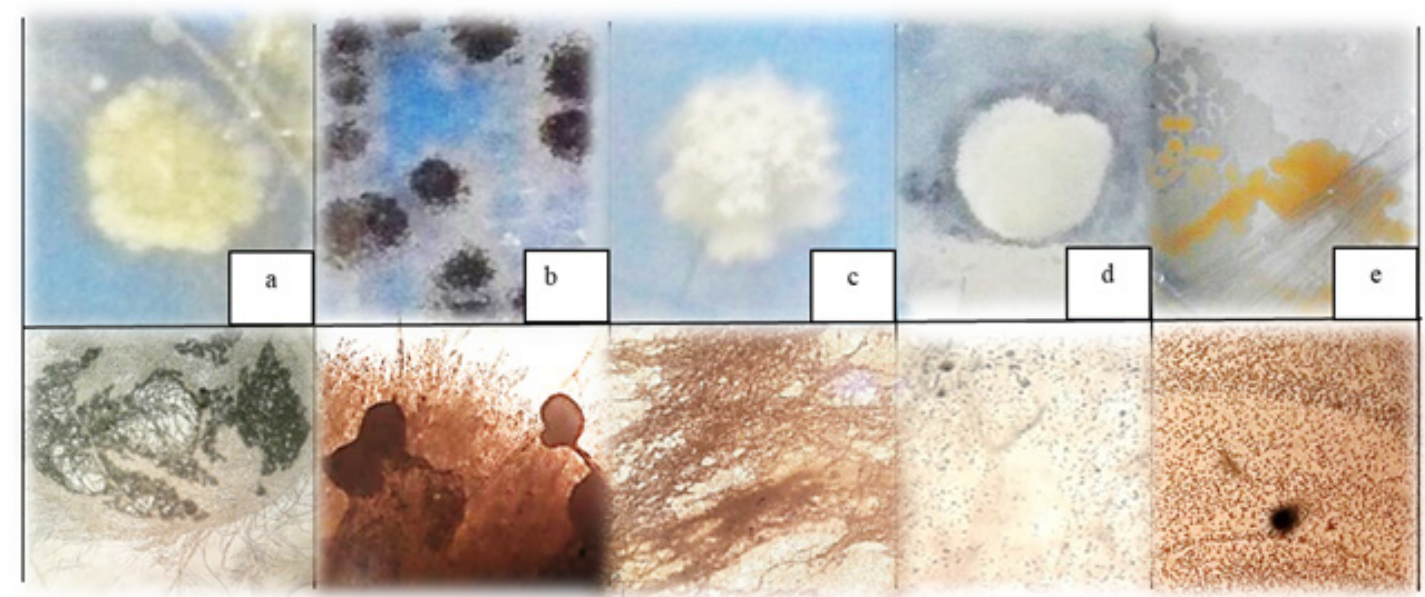

Figure 8. The fungi identification after enrichment with 10x (above) and 40x (below) magnification. Above column shows the colony, while the below column shows the cell (a: cream multicellular, b: black multicellular, c: white multicellular, d: white unicellular, e: yellow unicellular).

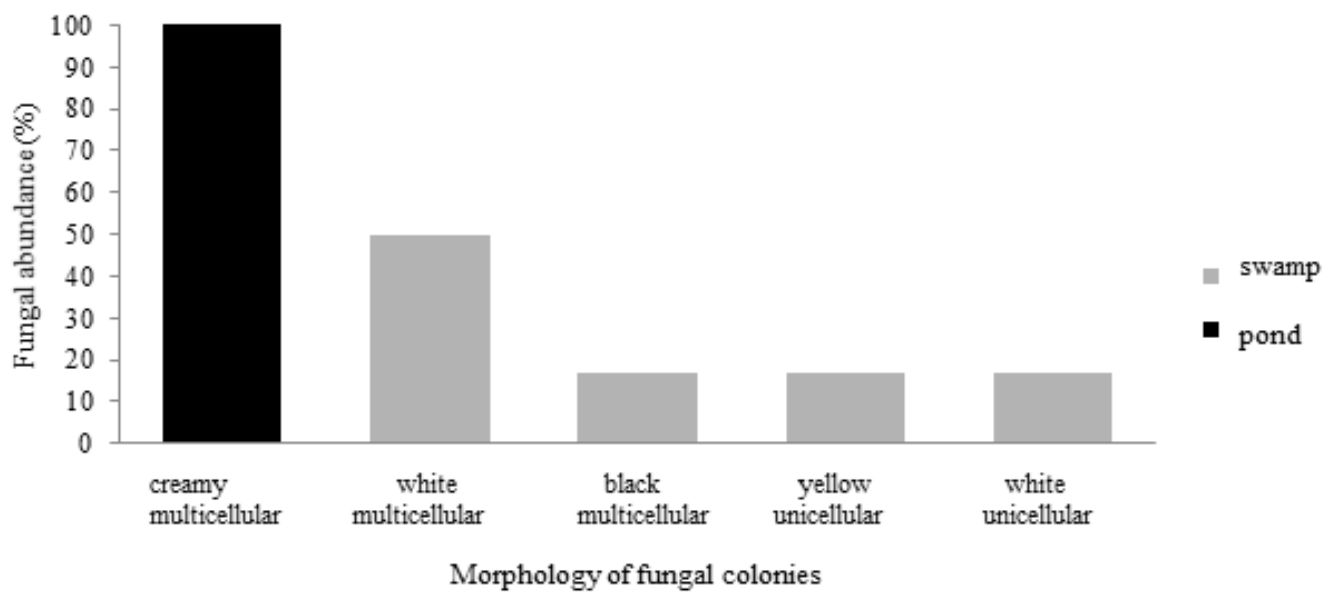

Figure 9. The fungal abundance on each habitat from swamp and pond

required for the phytoplankton photosynthesis in the pond (Cui \& Chui, 2017). The water quality of pond and swamp shows poor nutrient conditions, requiring fertilization to multiply the original microbes. The swamp water fertility of swamp ponds can be enhanced through the temporal water exchange from swamp forest and fertilization effort.

The microalgae (phytoplankton) identification was performed after the enrichment by adding microalgae, then aerated and agitated on the media for 7-14 days. The identification result indicates an increased microalgal quantity, although a reduction quantity occurs in the type that grew on technical culture media (Figure 5).

The identified microalgae contained on the enrichment media during the observation period were almost similar to those found in the natural habitat, dominated by Chlorella. The group analysis on pond 1 showed the farthest water quality uniformity from others. This may be caused by the role of freshwater when the rainwater was more dominant than seawater intrusion as seen on low salinity value ( 1 and $2 \mathrm{~g} / \mathrm{L}$ ) compared to the water salinity level on other locations $(<9 \mathrm{~g} / \mathrm{L})$. The electrical power also shows similar condition with salinity. Chlorella is the easiest growing type of phytoplankton/microalgae with broad salinity tolerance. Chlorella autotrophica or Chlorella sp. is a type of marine Chlorella that can adapt to the freshwater because of its euryhaline capability (Mansfeldt et al., 2016) This type of microalgae can be used as green water on the aquaculture system and live feed for zooplankton and shrimp. Chlorella can be an immune-boosting feed for post shrimp larvae with increased prophenoloxidase 
activity and total haematocyte, resisting $A$. hydrophila (Maliwat et al., 2016).

The plankton abundance in the origin and enrichment media shows different composition types (Figures 6 and 7). Some phytoplankton and zooplankton were still unable to be preserved while cultured on the enrichment medium. Conversely, there were phytoplanktons growing on the enrichment media, although unable to grow on the original media as stated in Figures 6 and 7 . This can be due to the different conformity of enrichment media for different phytoplankton types.

Chlorella dominated twice on the origin habitat media compared to other types (Figure 6). This happened as Chlorella can easily grow either in freshwater or brackishwater. High salinity level in the brackishwater induces lipid formation in Chlorella cells (Kakarla et al., 2018), making Chlorella retain the osmoregulation process with the lipid protection on the cell walls.

The highest phytoplankton abundance on the enrichment media consecutively is Chlorella, Oscilatoria, Gleocapsa, dan Aphanotece (Figure 7). Chlorella was still in the highest abundance on the enrichment media containing the anorganic technical fertilizer solution often utilized as the fertilizer media for cultivating Chlorella. This microalgae type is easily adapted to the various media from the fertilizer until the paper factory and aquaculture sewage media (Daneshvar et al., 2018).

Chlorophyta and Cyanophyta became the easiest group to be grown on the enrichment culture media (Figures 6 and 7). The microalgae identification after enrichment with the technical culture media improved these two groups quantity due to the different element requirement among the two groups and Bacillariophyta, specifically silicate element. Chlorophyta and Cyanophyta are unable to grow well in the media containing silicate instead of Bacillariophyta. The Bacillariophyta or diatoms desperately need silicate elements as the body structure constituent. This makes one of the determinant factors of this microalgae growth. According to Tilman et al. (1982), green and blue algae (Cyanophyta) will grow dominantly in the water when the phosphorus-silicate ratio $(\mathrm{Si}: \mathrm{P})$ is low, and nitrogen-phosphorus ratio $(\mathrm{N}: \mathrm{P})$ is high, and vice versa on the diatoms. In the natural habitat, nutrients and water surface fluctuation are the major factors affecting the phytoplankton composition, while water temperature and rainfall are very influential on Cyanophyta biomass (Yang et al., 2017). Nutrients affect the fluctuating phytoplankton composition based on the habits and nutrient utilization capability. Water surface fluctuation can affect the passive movement of phytoplankton, changing the composition type, while water temperature and rainfall can affect the Cyanophyta biomass as temperature and rainfall determine the water column height and $\mathrm{pH}$ level, making the Cyanophyta near the waterbase or substrate are more exposed to the sunlight during the low tide with the $\mathrm{pH}$ level was more than 7 (Issa et al., 2014). Some Cyanophyta such as Anabaena, Oscilatoria, Microcystis, and Nostoc in the nitrogen fixation process can be more functional when decreased nitrogen levels occurred in the water column (Issa et al., 2014).

Fungi that grew on PDA cultivation media were multicellular and unicellular fungi either from swamp or pond (Figure 8). The various types of fungi can live in the water habitat by forming layers attached to the substrate or sediment or forming floc in the water column. The density of filamentous fungi is higher in sediment than the water column. Although some environmental parameters are not ideal for fungi growth, the fungi can still survive. The fungi genera that can grow in water and mangrove sediments include Aspergillus, Penicillium, Cladosporium, and Fusarium. The fungi capabilities can be explored to produce some enzymes for the biotechnology and pharmaceutical industries (Doi et al., 2018).

The microscope observation on fungi grown in the pond was more diverse than in the swamp (Figure 9) without calculating the total fungi colony. One type of fungi was found dominating the swamp media, i.e the cream multicellular fungi colony, while two fungi types were found dominating the pond media, i.e yellow and white unicellular fungi colony. The pond media contains more organic materials from the feed and aquaculture biota metabolism waste, improving more fungi growth.

The cultured organisms, such as shrimps and milkfish, are the main factor that causes the inclusion of endogenous unicellular fungi in this study. This type of unicellular fungi, namely yeast, can be the source of single-cell protein feed, probiotics, and beta-glucan immunostimulatory material for the cultured organisms (Figure 9) (Meena et al., 2012). Multicellular fungi have the potential to produce polymeric substances (EPS) as the microbial binding material for bioflocs and 
biofilm formation (Decho \& Guiterrez, 2017). EPS can damage the performance and productivity of aquaculture facilities and contribute to the attack of harmful phytoplankton against the cultured species. However, EPS can also provide a positive influence on the aquaculture activities by increasing the resistance of cultured larvae and remediate the culture waste during the bioflocculation process. EPS is even applicable to the industrial biotechnology aquaculture as an antiviral and immunostimulants agent, as well as anti-biofouling agents (Camacho-Chab et al., 2016). Extracellular polysaccharides can induce nonspecific immune mechanisms and disease resistance in fish (Zhang et al., 2019). Fungi grew on the culture dish were still unknown. Branchiomyces are fungi with negative character causing the mass mortality in tilapia pond culture even the dissolved oxygen level is still above 4 $\mathrm{mg} / \mathrm{L}$ (Abu-Elala et al., 2016). It is important to ensure that the fungi characteristics isolated from the locations were not pathogenic, toxic, or containing the anti-nutrient substances.

The presence of various fungi and microalgae can be used as the biofloc candidates. Microalgae can form flocs with other microbes such as bacteria, fungi or other microalgae as long as there are flocculation agents, such as polysaccharides (Ummalyma et al., 2017). The utilization of microbial bioflocculants can be applied as a natural feed in aquaculture when the feed conditions are fulfilled, i.e nonpathogenic, non-toxic, not producing anti-nutrients, and can be consumed by target biota. Both eukaryote microbes with their symbiotic potential to form bioflocs still needs a further study, considering less information regarding the eukaryotic microbial consortium for the environmental, feed, and disease maintenance in the development of efficient and environmentally friendly aquaculture.

The ongoing development of the world's aquaculture demands new strategies and alternatives to achieve sustainable development. Microbial-based systems are one of the most appropriate strategies for achieving sustainable aquaculture. This system is based on the advantages of microbial proliferation, containing the autotrophic or heterotrophic microorganisms. The use of microbes can recycle and alter the excess nutrients from wastes, dead organisms, unconsumed feed, and various metabolites into microbial biomass, which are further consumed by the cultured organisms (Martinez-Cordova et al., 2014).

\section{CONCLUSION}

Microalgae that can be grown on the culture media come from the group of Chlorophyta and Cyanophyta, while the fungi grown on PDA media from the brackishwater ponds and swamp come from the group of multicellular and unicellular fungi. Both eukaryote microbes have the potential as the biofloc formers in the sustainable development of swamp aquaculture.

\section{ACKNOWLEDGEMENTS}

Authors would like to thank the University of Sriwijaya who has funded this study as excellent competitive research on the University of Sriwijaya in 2016 and 2017.

\section{REFERENCES}

Abu-Elala NM, Abd-Elsalam RM, Marouf S, Abdelazis M, Moustafa M. 2016. Eutrophication, ammonia intoxication, and infectious diseases: interdisciplinary factors of mass mortalities in cultured Nile tilapia. Journal of Aquatic Animal Health 145: $187-$ 198.

Addo MG, Woods CA, Andoh LA, ObiriDanso K. 2016. Effect of varying storage temperatures on the microbiological quality of street sold water in the Kumasi metropolis Ghana. Research Journal of Microbiology 11: 56-63.

Boaventura CM, Coelho FJRC, Martins PT, Pires ACC, Duarte LN, Uetanabaro APT, Cleary DFR, Gomes NCM. 2018. Micro-eukaryotic plankton diversity in an intensive aquaculture system for production of Scophthalmus maximus and Solea senegalensis. Aquaculture 490: 321-328.

Camacho-Chab JC, Lango-Reynoso F, Castañeda-Chávez MdTR, Galaviz-Villa I, Hinojosa-Garro D, Ortega-Morales BO. 2016. Implications of extracellular polymeric substance matrices of microbial habitats associated with coastal aquaculture systems. Water 369: 1-21.

Crab R, Defoirdt T, Bossier P, Verstraete W. 2012. Biofloc technology in aquaculture: beneficial effects and future challenges. Aquaculture 356-357: 351-356.

Cui W, Chui TFM. 2017. Temporal variations in water quality in a brackish tidal pond: 
Implications for governing processes and management strategies. Journal of Environmental Management 193: 108-117.

Daneshvar E, Antikainen L, Koutra E, Kornaros M, Bhatnagar A. 2018. Investigation on the feasibility of Chlorella vulgaris cultivation in a mixture ofpulp and aquaculture effluents: treatment of wastewater and lipid extraction. Bioresource Technology 255: 104-110

Davis CC. 1955. The Marine and Fresh Water plankton. East Lansing: Michigan State University.

Decho AW, Gutierrez T. 2017. Microbial extracellular polymeric substances (EPSs) in ocean systems. Frontiers in Microbiology 8: 922.

De Melo ML, Bertilsson S, Amaral JHF, Barbosa PM, Forsberg BR, Sarmento H. 2018. Flood pulse regulation of bacterioplankton community composition in an Amazonian floodplain lake. Freshwater Biology 00: 1-13.

Doi SA, Pinto AB, Canali M C, Polezel DR, Merguizo RAC, de Oliveira AJFC. 2018. Density and diversity of filamentous fungi in the water and sediment of Araçá Bay In São Sebastião, São Paulo, Brazil. Biota Neotropica 18: 1-9.

Easson CG, Lopez JV. 2019. Depth-dependent environmental drivers of microbial plankton community structure in the northern gulf of Mexico. Frontiers in Microbiology 9: 3175.

Holland A, Duivenvoorden LJ, Kinnear SHW. 2012. Naturally acidic waterways: conceptual food webs for better management and understanding of ecological functioning. Aquatic Conservation Marine and Freshwater Ecosystem 22: 836-847.

Issa AA, Abd-Alla MH, Ohyama T. 2014. Nitrogen Fixing Cyanobacteria: Future Prospect, in: Ohyama $\mathrm{T}$ ed. Advances in Biology and Ecology of Nitrogen Fixation 2: 24-48.

Kakarla R, Choi JW, Yun JH, Kim BH, Heo J, Lee S, Cho DH, Ramanan R, Kim HS. 2018. Application of high-salinity stress for enhancing the lipid productivity of Chlorella sorokiniana HS1 in a two-phase process. Journal of Microbiology 56: 56-64.

Kumaran M, Sundaram M, Mathew S, and Anand PR. 2018. Socio-personal contour, information flow and productivity of brackishwater aquaculture systems - an appraisal. Journal of Extension Education 30: 6119-6128.

Madigan MT, Bender KS, Buckley DH, Sattley WM, Stahl DA. 2020. Brock biology of microorganisms. Fifteenth edition. Pearson Education, Inc. United States of America.

Maliwat GC, Velasquez S, Robil JL, Chan M, Traifalgar RF, Tayamen M, Ragaza JA. 2016. Growth and immune response of giant freshwater prawn Macrobrachium rosenbergii (De Man) postlarvae fed diets containing Chlorella vulgaris (Beijerinck). Aquaculture Research 4: 1666-1676.

Mansfeldt CB, Richter LV, Ahner BA, Cochlan WP, Richardson RE. 2016. Use of de novo transcriptome libraries to characterize a novel oleaginous marine chlorella species during the accumulation of triacylglycerols. PLoS ONE 11: 1-21.

Martinez-Cordova LR, Emerenciano M, MirandaBaeza A, and Martınez-Porchas M. 2014. Microbial-based systems for aquaculture of fish and shrimp: an updated review. Reviews in Aquaculture 6: 1-18.

Martinez-Porchas M, Martinez-Cordova LR. 2012. World aquaculture: environmental impacts and troubleshooting alternatives. The Scientific World Journal 2012: 1-9.

Meena DK, Das P, Kumar S, Mandal SC, Prusty AK, Singh SK, Akhtar MS, Behera BK, Kumar K, Pal AK, Mukherjee SC. 2012. Beta-glucan: an ideal immunostimulant in aquaculture (a review). Fish Physiology and Biochemistry 39: 431-457.

Pérez-Fuentes JA, Hernández-Vergara MP, Pérez-Rostro CI, Fogel I. 2016. C:N ratios affect nitrogen removal and production of Nile tilapia Oreochromis niloticus raised in a biofloc system under high density cultivation. Aquaculture 452: 247-251.

SNI 6418.3.2013: Ikan Bandeng Chanos chanos (Forskal) bagian 3 produksi benih, BSN, Jakarta.

Tilman D, Kilham SS, Kilham P. 1982. Phytoplankton community ecology: the role of limiting nutrients. Annual Review Ecology \& Systematics 13: 349-372.

[WWF] World Wide Fund Indonesia. 2014. Best Practice Management, Budidaya Ikan Bandeng Chanos chanos. Jakarta: WWF Indonesia 
Ummalyma SB, Gnansounou E, Sukumaran RK, Sindhu R, Pandey A, Sahoo D. 2017. Bioflocculation: An alternative strategy for harvesting of microalgae-an overview, Bioresource Technology 242: 227-235.

Venkatachalam S, Kandasamy K, Krishnamoorthyc I, Narayanasamyd R. 2018. Survival and growth of fish Lates calcarifer under integrated mangrove aquaculture and open-aquaculture systems. Aquaculture Reports 9: 18-24.

Yang JR, Hong Lv, Isabwe A, Liu L, Yu X, Chen H, Yang J. 2017. Disturbance-induced phytoplankton regime shifts and recovery of cyanobacteria dominance in two subtropical reservoirs. Water Research 120: 52-63.

Wijayanti M, Wahyudi AT, Yuhana M, Engelhaupt M, Meryandini A. 2019. Impact of Bukit Dua Belas rainforest transformation to oil palm plantation on phylogenetic of soil bacterial communities in Sarolangun, Jambi, Sumatra, Indonesia. Biodiversitas 20: 811-818.

Zhang Z, Chi H, Dalmo RA. 2019. Trained innate immunity of fish is a viable approach in larval aquaculture. Frontiers in Immunology 10: 42 